\title{
EXPERIMENTAL RESULTS ON PERMEABLE PAVEMENTS IN URBAN AREAS: A SYNTHETIC REVIEW
}

\author{
M. MARCHIONI \& G. BECCIU \\ Department of Civil and Environmental Engineering, Politecnico di Milano, Italy.
}

\section{ABSTRACT}

Permeable pavements can reduce volumes and improve water quality of stormwater runoff by allowing water to infiltrate on its structure, easily integrating with other water control strategies in sustainable urban drainage systems. This solution is already well known, commercially available and referred to on many municipal legislations. This literature review discuss the role of permeable pavements in urban drainage by analyzing the main results on full-scale tests, especially regarding runoff volume reduction and quality improvement. Research results and case studies reported in literature confirm both the feasibility and the benefits of the use of permeable pavements in urban areas, even though research is still required on some application issues.

Keywords: permeable pavement, SUDs, sustainability, urban drainage.

\section{INTRODUCTION}

As urbanization increases, the urban drainage system becomes gradually overloaded, with frequent spills to receiving water bodies of polluted water and uncontrolled flooding on critical areas. Upgrade or re-design the existing system is not an effective solution because it does not act on the causes. Instead, it is necessary strategies for urbanization reduction and 'upstream' stormwater control [1]. These strategies are aimed to reduce stormwater runoff mainly through water retention, detention and infiltration enhancement before inflow to the drainage system. The philosophy behind these measures is to restore a water cycle balance closest possible to the pre-development conditions and, at the same time, improve water quality and preserve biodiversity in the receiving water bodies. These measures are commonly referred as Stormwater Best Management Practice (BMPs) [2] and the resulting drainage systems as sustainable urban drainage systems (SUDs) [3] or low-impact development (LID) stormwater drainage systems [4]. In SUDs, several solutions are combined to achieve these aims, ranging from green roofs to detention ponds, according to urban constrains, social, economic and environmental issues [5].

Comparing to other solutions, permeable pavements are highly effective and easily applicable. They do not need additional space to act on reduction of surface runoff volume and they may be used both for direct water infiltration into the ground and for water retention and detention [2].

Another issue of interest on SUDs is water quality, considering that stormwater is related with non-punctual pollution which shows a more complex control and can often be the main source for stream pollution. Permeable pavement can enhance the water quality through mechanisms of sedimentation, filtration, adsorption, biodegradation and volatilization, allowing nutrient, sludge, heavy metals and hydrocarbons removal [3].

Quality enhancement can promote also the reuse of water collected by permeable pavements, and in combination with photocatalytic cement they can also reduce air pollutants, improving also air quality [6].

Early studies on permeable pavements date from the 1970s and were mostly conducted on laboratory, normally using rainfall simulation [7]. The first full-scale tests were held starting at the 1980s as shown in Table 1. Those studies mostly evaluated the efficiency of pavements on reducing runoff volume and pollutants removal testifying its effectiveness as SUDs, as well as confirming locally its availability. More details about the mentioned researches on Table 1 are mentioned thoroughly in the text.

(C) 2015 WIT Press, www.witpress.com

ISSN: 1743-7601 (paper format), ISSN: 1743-761X (online), http://www.witpress.com/journals DOI: $10.2495 /$ SDP-V10-N6-806-817 
M. Marchioni \& G. Becciu, Int. J. Sus. Dev. Plann. Vol. 10, No. 6 (2015)

807

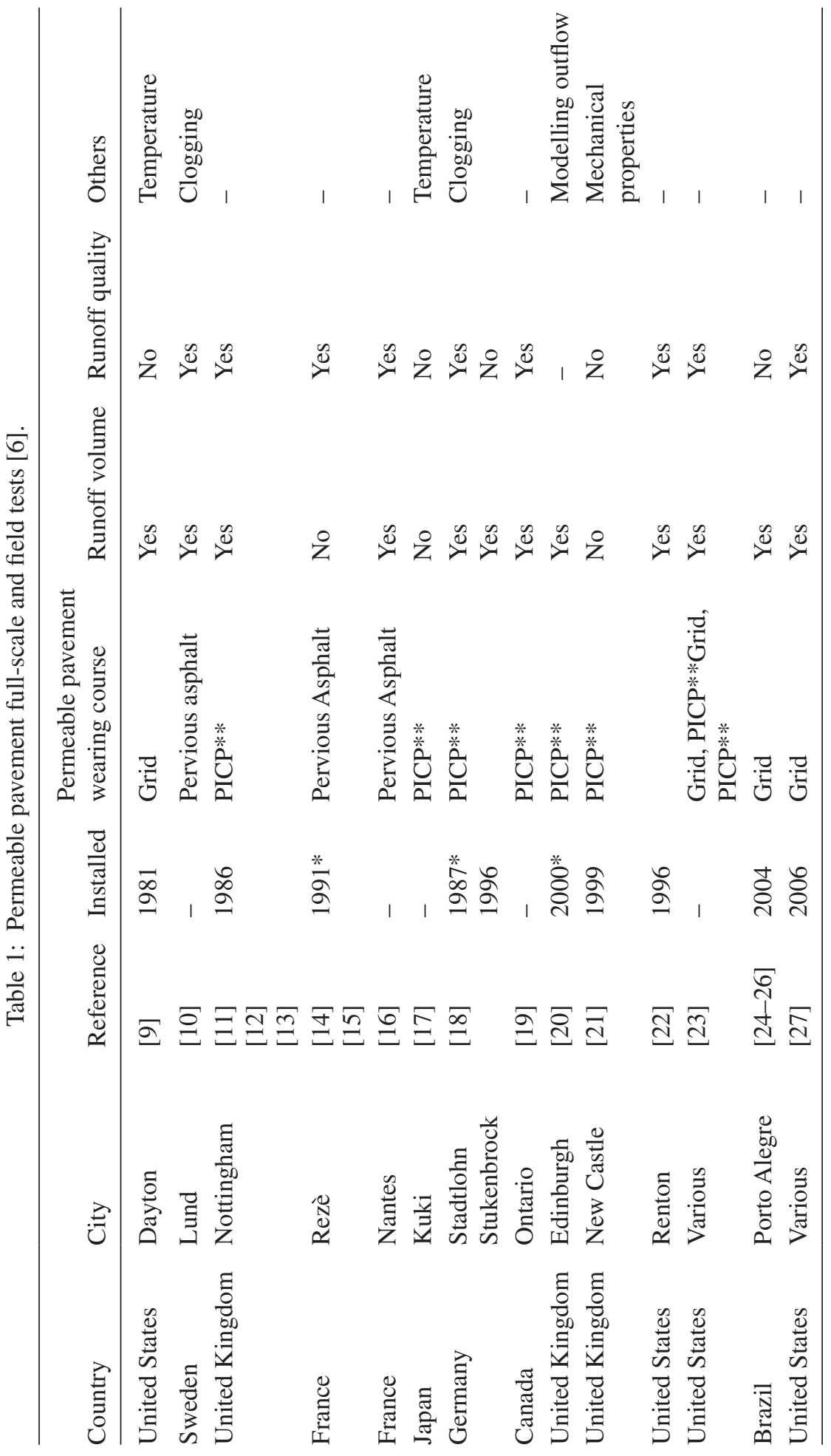




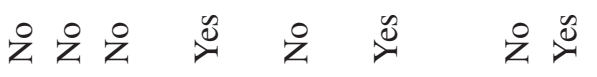

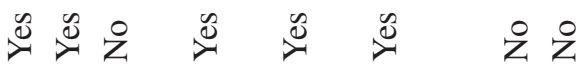

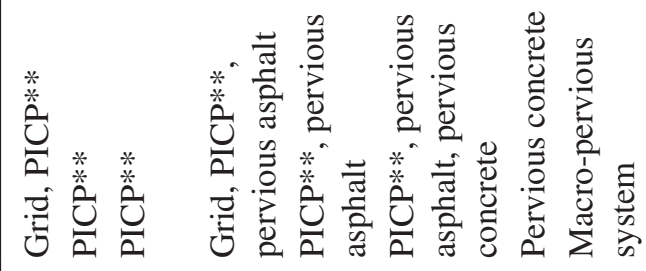

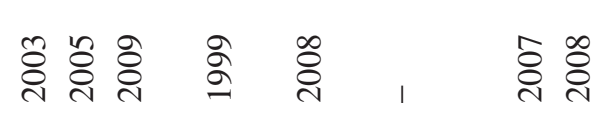

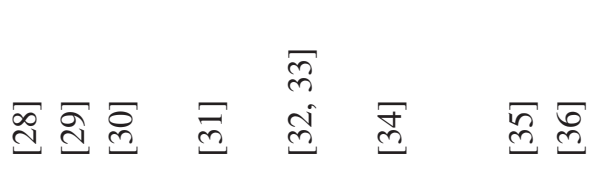

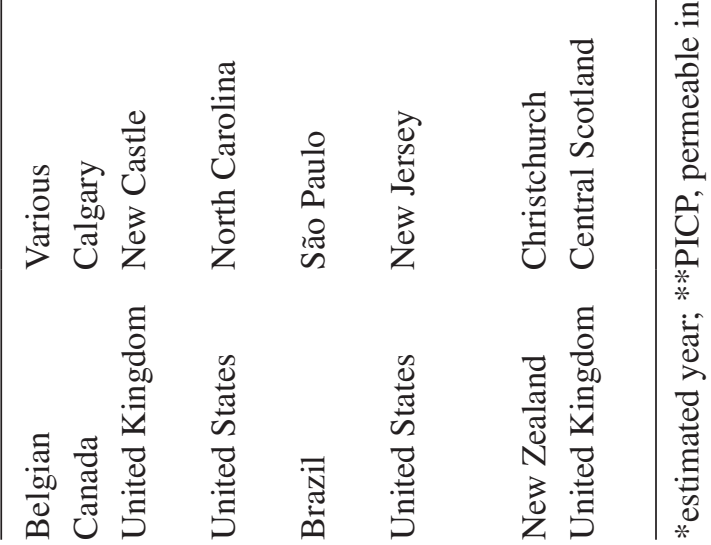




\section{DEFINITION AND BACKGROUND}

Permeable pavements must allow water to infiltrate; therefore, they show a high porosity structure with open and interconnected spaces where water and air can pass through. Infiltration must be fast enough to avoid the possibility of significant ponding for most rainfall events. Although they are often referred as porous pavements in literature, it is important to notice that all pavements present some level of porosity; thus, it is more accurate to use the terms permeable or pervious meaning that it is capable of being permeated by liquid or gas.

Various kinds of surfaces may be used for those pavements: concrete blocks, in placed pervious concrete, pervious asphalt, concrete grids, aggregates, grass, plastic grids, granular materials and loose decks [8]. The ones that provide vehicular support are concrete blocks used on permeable interlocking concrete pavement, in place pervious concrete and pervious asphalt.

The pavement base/sub-base is similar to the conventional one. The main difference is the aggregate void rate, which must be such that it allows the base to perform as a water reservoir [37]. The high void content results on less strength; for that reason, permeable pavements are normally applied on areas with low volume traffic and with limited heavy vehicle loading [38].

\section{RUNOFF VOLUME}

The primary role of a permeable pavement is to reduce runoff volume and promote hydrograph attenuation. Therefore, this feature was considered on the majority of researches, mainly addressing the effect of the type of surface and structure on runoff coefficient, peak flow attenuation, quality (Table 1).

Results on runoff coefficient are reunited In Table 2 showing reduction when compared to traditional pavement that normally ranges between 0.90 and 1.00 .

The full-scale tests mentioned in Table 2 recorded the results with different observation periods. Smith [9] obtained the results for 11 storm events, Pratt [11] initially observed the pavements during a 30-day period, noticing also a delay of many hours after the rainfall started, and later on Pratt and Mantle [12] recorded the results for 62 rainfall events. Acioli [24] monitored for a year a parking lot. Dreelin and Fowler [27] monitored the pavement installed over clay soil for a year after Bean and Hunt [23] observed lower infiltration rates on permeable pavements over clay soils when compared with sandy soils.

Suda and Yamanaka [39] used a rainfall simulator over permeable interlocking concrete pavement with pervious concrete blocks. For the first $30 \mathrm{~min}$ of a $50 \mathrm{~mm} / \mathrm{h}$ constant intensity rainfall, no runoff was observed.

Pagotto and Legret [16] tested a pervious asphalt pavement for a year, comparing results with those from a conventional asphalt pavement installed on the same site (Table 3). In this case, the

Table 2: Runoff coefficient on permeable pavement full-scale tests.

\begin{tabular}{lcc}
\hline Reference & Types of pavement & Runoff coefficient range \\
\hline$[9]$ & Grid & $0.00-0.35$ \\
{$[12]$} & PICP & $0.37-0.45$ \\
{$[22]$} & Grid, PICP & $0.00-0.03$ \\
{$[24]$} & Grid & $0.00-0.10$ \\
{$[27]$} & Grid & $0.00-0.26$ \\
\hline
\end{tabular}

PICP: permeable interlocking concrete pavement. 
pervious asphalt was installed over an impervious surface, therefore, could not be considered a fully permeable pavement. Runoff from pervious asphalt was $7825 \mathrm{~m}^{3} / \mathrm{ha}$ while conventional value $5840 \mathrm{~m}^{3} / \mathrm{ha}$, confirming the importance of a fully permeable base to reduce runoff. On the other side, the time lag between rainfall and runoff was higher for the pervious asphalt than for conventional asphalt (2:30 $\mathrm{h}$ versus $1: 15 \mathrm{~h})$.

Most of the tests reported above were done mostly for research. Beeldens and Herrier [28], on the other hand, monitored 50 sites of existing pavements with up to 10 years of life (Table 4). Using a

Table 3: Comparison on wearing course applied on highway [16].

\begin{tabular}{lcc}
\hline & Conventional (1995-1996) & Pervious Asphalt (1997-1998) \\
\hline Number of rain events & 125 & 162 \\
Total depth of rainwater (mm) & 698 & 796 \\
Total duration of events with & 646 & 774 \\
runoff (h) & 5840 & 7825 \\
Flow volume (m $\left.{ }^{3} / \mathrm{ha}\right)$ & 1108 & 1457 \\
Total duration of flow (h) & 0.84 & 0.98 \\
Mean of runoff coefficient & $1: 15$ & $2: 30$ \\
Mean of response time (h:min) & & \\
\hline
\end{tabular}

Table 4: Field measurements in Belgium [28].

\begin{tabular}{|c|c|c|c|c|c|}
\hline Project & $\begin{array}{c}\text { Type of } \\
\text { pavement }\end{array}$ & $\begin{array}{c}\text { Year of } \\
\text { construction }\end{array}$ & $\begin{array}{c}\text { Year of } \\
\text { measurement }\end{array}$ & $\begin{array}{c}\text { Surface } \\
\text { permeability* } \\
(\mathrm{m} / \mathrm{s})\end{array}$ & Notes \\
\hline \multirow{3}{*}{$\begin{array}{l}\text { Shopping } \\
\text { Centre } \\
\text { Waasland, } \\
\text { Sint-Niklaas }\end{array}$} & Pervious block & 2003 & 2003 & $4.3 \times 10^{-4}$ & - \\
\hline & & & 2005 & $7.6 \times 10^{-5}$ & $\begin{array}{l}\text { Without filling } \\
\text { the joints }\end{array}$ \\
\hline & & & 2005 & $2.5 \times 10^{-5}$ & $\begin{array}{l}\text { Filling the } \\
\text { joints }\end{array}$ \\
\hline De Panne & Pervious block & 1998 & 2004 & $1.69 \times 10^{-4}$ & - \\
\hline Zuttendaal & $\begin{array}{l}\text { Enlarge joints } \\
\text { block }\end{array}$ & 2004 & 2004 & $1.03 \times 10^{-3}$ & - \\
\hline $\begin{array}{l}\text { Heist-op- } \\
\text { den-Berg }\end{array}$ & - & 2000 & 2004 & $4.4 \times 10^{-4}$ & - \\
\hline Evergem & - & 2001 & 2004 & $2.38 \times 10^{-5}$ & $\begin{array}{l}\text { Cleaned using } \\
\text { high pressure } \\
\text { after flooding } \\
\text { with mud }\end{array}$ \\
\hline
\end{tabular}

*Using double-ring infiltrometer. 
double-ring infiltrometer, they found out acceptable overall performance on surface infiltration and storage capability, highlighting the importance of the base thickness and the subgrade soil infiltration rate.

Full-scale and fields tests provide also information for the development and calibration of mathematical models. Schlüter and Jefferies [20] used the Erwin 3.0 rainfall-runoff model with adaptations to estimate the outflow volume from an existing permeable pavement in Edinburgh, Scotland, achieving acceptable agreement for both peak flow and volume. Qin and Li [40] used USA EPA's SWMM for the simulation of permeable pavements and to investigate the impact of SUDs on a China development area. Sansalone and Raje [41] also used SWMM for simulation of permeable pavements on a Florida development area.

Elliott and Trowsdale [4] listed 40 models and reviewed 10 that were available and with sufficient information. None of these models were considered fully able to simulate all the features of permeable systems and their use was suggested mainly for preliminary design at the planning level. Therefore, a gap between present modeling capabilities and engineering application needs was identified.

\section{RUNOFF QUALITY}

In [11], it was analyzed the short- and long-term variations of pollutant concentration and masses in runoff from permeable pavements. Four different stones for the pavement base were tested in laboratory. Ten years of rainfall were simulated, with different results on the runoff water quality. For example, $\mathrm{pH}$ and alkalinity was reduced by using blast furnace slag, while reduction of hardness and lead discharge was achieved by using limestone. However, in long term, the effects of stone variation were reduced due to reduction of chemical degradation. Reduction of suspended solids in runoff was also reported, with concentration ranging from near 0 (zero) to $50 \mathrm{mg} / \mathrm{L}$, while on an impermeable pavement fluctuate from 30 to $300 \mathrm{mg} / \mathrm{L}$, with peaks of $1000 \mathrm{mg} / \mathrm{L}$. Also fine sediments, organic material and lead accumulation through the pavement layers were analyzed. With small variations among the types of base, the larger part of sediments was trapped on the gravel layer above the geotextile. Later on, Pratt and Newman [42] studied the ability of the pavement to retain and treat petroleum-derived pollutants through microbial bio-degradation obtaining a $97.6 \%$ of efficiency, although they recommend care on the use of nutrients to avoid the risk of effluents eutrophication.

The pollutants removal was also addressed by Legret and Colandini [14] using a pervious asphalt surface, pervious bitumen stabilized base, crushed stones sub-base and a geotextile above the subgrade. After analyzing 30 rainfall events and comparing results from a nearby impermeable pavement, the permeable pavement showed a decrease of about $64 \%$ in suspended solids and $79 \%$ in lead concentration. After 4 years, the structure of the pavement was analyzed, revealing that the micropollutants tend to accumulate on the pervious asphalt and the geotextile level, while contamination of the soil was not observed.

A similar test was done by Legret and Colandini [15], observing a reduction of suspended solids, $\mathrm{Pb}, \mathrm{Cu}, \mathrm{Cd}$ and $\mathrm{Zn}$ in pavement runoff. Samples extracted from the pavement structure and from the soil below showed that metals are mainly retained on the pervious asphalt and that the soil did not show signs of contamination after 8 years (Fig. 1).

Kirkpatrick et al. [48] discussed the role of the geotextile on the pollutants removal, reporting that a $93.1 \%$ hydrocarbons removal was achieved without the use of geotextile. Also in Dierkes and Kuhlmann [18], the tests conducted with pervious concrete permeable interlocking concrete pavement showed that most of the heavy metals were trapped on the upper layer of the pervious concrete blocks. Mullaney and Rikalainen [43] arrived at the same conclusion reporting that up to $60 \%$ of metals were trapped on the upper layers, with or without geotextile. 


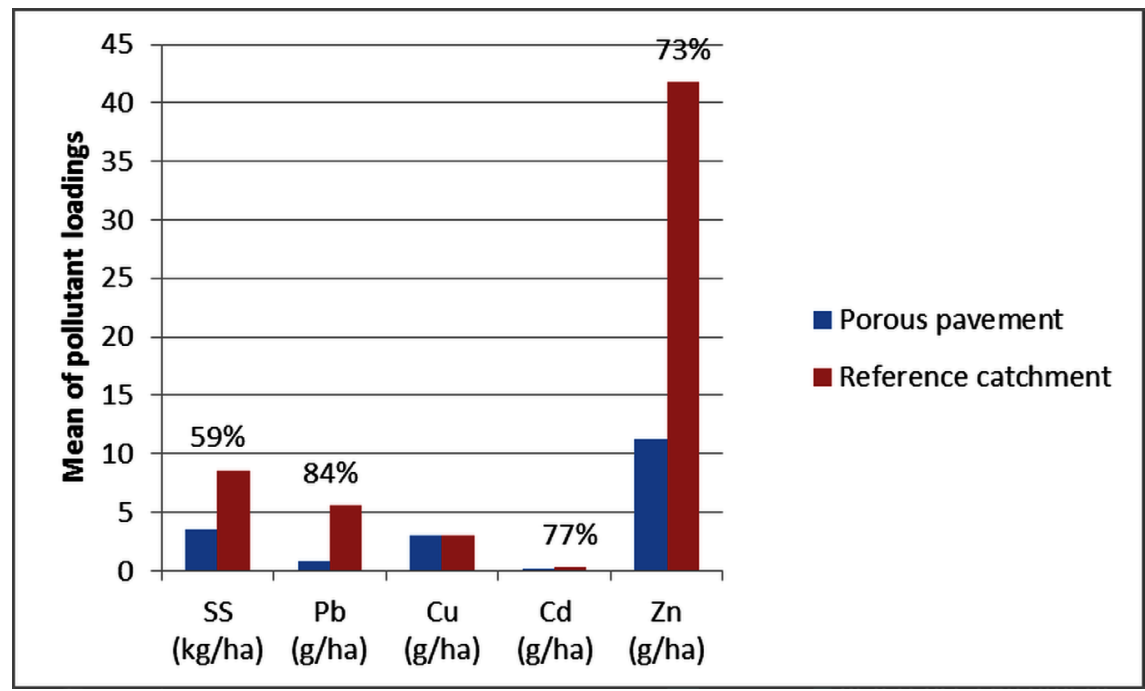

Figure 1: Comparison between mean pollutant loads after 8 years of operation using pervious asphalt [15].

Instead of analyzing the water outflow, Morgenroth and Buchan [35] analyzed the soil below 25 sites with different surfaces: no pavement, conventional pavement and permeable pavement. They observed that permeable pavements may alter physical and chemical characteristics of soils, with a potential impact on vegetation. Particularly, alterations on soil $\mathrm{pH}$, with effects on soil solubility, and on metals' concentration, with a reduction of $\mathrm{Al}, \mathrm{Fe}$ and $\mathrm{Mg}$ and an increase of $\mathrm{Na}$. The effects were dependent upon soil initial conditions.

Although the mentioned studies were mainly focused on physical-chemical pollutants, the effect of microorganism must also be taken into account. For instance, fecal pollution can cause health risks by affecting water sources and also economical loss, e.g. by beaches closures [44]. In [45], it is reported that the use of permeable interlocking concrete pavement combined with titanium dioxide on a laboratory experiment was able to completely remove from runoff Escherichia coli, total coliforms and fecal Streptococci through photocatalytic reaction.

In literature, some models have been proposed for the simulation of the effects of permeable pavements on water quality. The already mentioned SWMM can be also used to model runoff quality $[40,41,46]$. Imteaz and Ahsan [47] analyzed the accuracy of the Model of Urban Stormwater Improvement Conceptualization (MUSIC) by comparing the results with field measurements. They observed that the model overestimates the runoff reduction and consequently also the pollutants removal, suggesting that physically based models should be used to achieve a better accuracy.

\section{DESIGN LIFE AND MAINTENANCE}

Although permeable pavements usually shows good performances, there is a concern on efficiency loss during their design life due to clogging. After testing a number of pavements using an infiltrometer, Borgwardt [48] concluded that after 20 years a permeable pavement could lose $80 \%$ of its initial infiltration rate. Several other studies demonstrate that sediments are usually trapped on the upper layers; thus, remedial work would concentrate there [11,15,18,19,43].

Pratt [11] affirmed that paving blocks would show an advantage on maintenance, because in that case it consists only in removing the joint material and the bedding layer, while monolithic surfaces 
might require reinstallation. For instance, after 9 years of use, Jabur [25] conducted single-ring infiltrometer tests on the same pavement studied by Acioli [24] observing that the pervious asphalt was almost fully clogged while the concrete grids was still functional. Also, on an full-scale experiment in Calgary, Canada, Van Duin and Brown [29] observed that after 10 months of use the pervious asphalt was completely clogged, probably due to winter sand and traffic load, and even maintenance using vacuum sweeping could not increase infiltration. On the other hand, the portion of the pavement with permeable interlocking concrete pavement showed improvement after maintenance by removing the clogging material from joints. The author commented that modification on the mix design of the pervious asphalt could improve its performance.

On a field test conducted by Dierkes and Kuhlmann [18], the infiltration capacity was measured using a drip-infiltrometer before and after cleaning using a high-pressure cleaner with direct vacuum suction. Before remedial works, all points showed an infiltration capacity below $1 \mathrm{~mm} /(\mathrm{s} \mathrm{ha})$, much lower than the $270 \mathrm{l} /(\mathrm{s}$ ha) required by local law. However, after maintenance the infiltration capacity reached values between 1545 l/(s ha) and 5276 l/(s ha). On the work of Pellizzari [26], maintenance was held on the permeable pavement mentioned on Acioli [24], using a pressure jet cleaning machine, manual, and also obtained an increasing on infiltration (Fig. 2).

Using an adaptation of a soil infiltration test, the double-ring infiltrometer, Bean and Hunt [23] analyzed the surface infiltration on 27 paved sites with ages ranging from 6 months to 20 years, on initial conditions and after maintenance. The average infiltration for permeable interlocking concrete pavement with enlarged joints was $8.0 \mathrm{~cm} / \mathrm{h}$. After maintenance, it reached on average $2000 \mathrm{~cm} / \mathrm{h}$ on sites without soil disturbance and $61 \mathrm{~cm} / \mathrm{h}$ on others. Analyzing the physical mechanisms of clogging, Yong and McCarthy [49] punctuated the need for modeling of biological processes.

\section{EVALUATION}

For practical matters, it becomes essential to have both an accurate and simple method to evaluate the permeable pavement performance, especially to obtain municipality acceptance. The first issue

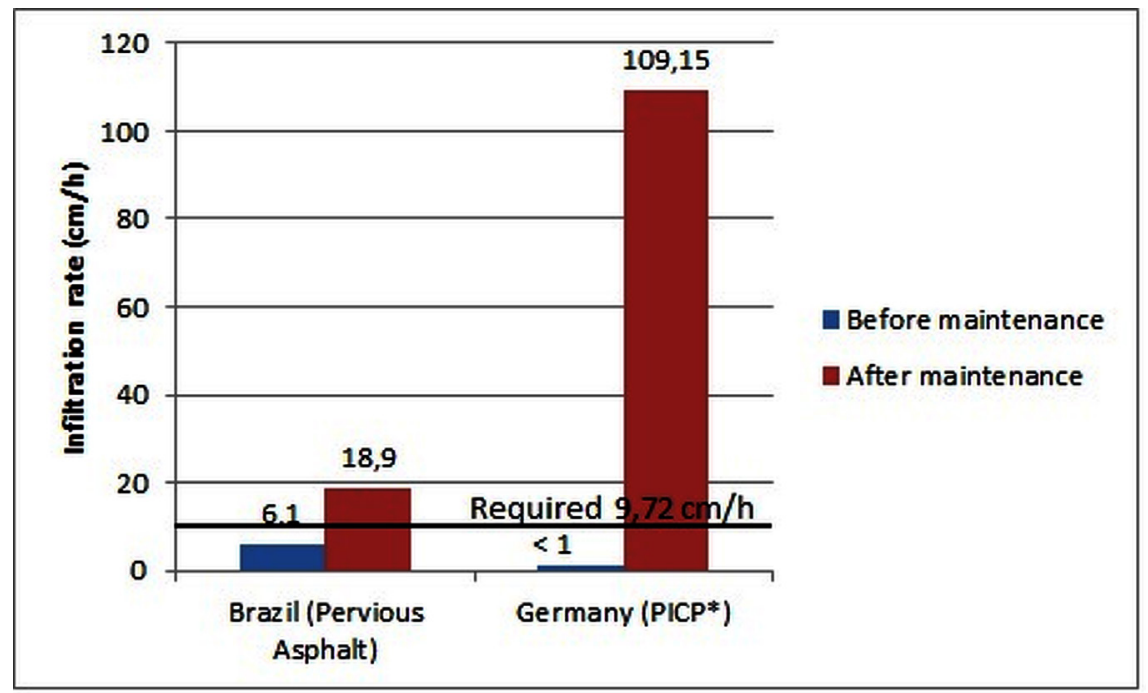

Figure 2: Infiltration rate before and after maintenance $[18,26]$. *PICP: permeable interlocking concrete pavement. 
is to evaluate the infiltration rate [50]. Common in soil classification, a soil that shows an infiltration rate above $4.10 \mathrm{~cm} / \mathrm{s}$ is considered having good permeability [51]. A permeable pavement, thus, should present a similar range to behave as a permeable soil [52]. In Germany, it is required that permeable pavements have an infiltration coefficient above $2.7 \times 10^{-5} \mathrm{~m} / \mathrm{s}[18]$.

The infiltration rate is directly obtained in soils by in place tests or using a constant or variable head permeameter or indirectly by size distribution analysis [51]. Bean and Hunt [23] adjusted a soil test method for permeable pavements, which was used as a base for the draft of ASTM [53]. This method has been reviewed by Smith and Earley [54] and Li and Kayhanian [55], who also analyzed the test method by the National Center for Asphalt Technology (NCAT). They both attested the effectiveness of the [53] test method. The test method was successfully applied on field tests by Borst [34], Marchioni and Silva [52] and Jabur [25], confirming its simple operation and accurate results.

\section{CONCLUSION}

Test results reported in literature confirm the effectiveness of permeable pavements in SUDs, for runoff volume reduction and pollutants removal from stormwater in urban areas, and their use should be encouraged.

To guarantee good performances, the pavement design must consider both mechanical and hydrological features. Particularly, it is important to consider a proper permeability through the entire structure, providing surface material with good infiltration rate, an open-graded base and considering the infiltration rate of the subgrade soil.

The base should have a high void content to behave as a reservoir while still provide the necessary mechanical strength. Even though clogging may occur, permeable pavements can regain acceptable infiltration rates through maintenance. To extend the design life, it is important to guarantee the characteristics of the surface layer and observe the adjacent areas.

Although there are a number of models for stormwater simulation and management, there is still the need of a set of more specific modeling tools that are able to link all the main issues related to permeable pavement application, as outflow volume, pollutants removal, mechanical performance and design life aspects. Finally, theoretical and experimental research is also needed to improve their performances and applicability, especially for roads with heavy traffic loads.

\section{REFERENCES}

[1] Paulo, S., Manual de Drenagem e manejo de águas pluviais: gerenciamendo do sistema de drenagem urbana, ed. S.M.d.D.U. (SMDU), Editor, São Paulo. p. 168, 2012. doi: http://dx.doi. org/10.11606/t.90.2014.tde-22082014-152009

[2] Field, R. \& Tafuri, A.N., The Use of Best Management Practices (BMPs) in Urban Watersheds, DEStech Publications, 2006.

[3] Woods-Ballard, B., et al., The SUDS Manual (C697), CIRIA, 2007.

[4] Elliott, A.H. \& Trowsdale, S.A., A review of models for low impact urban stormwater drainage. Environmental Modelling \& Software, 22(3), pp. 394-405, 2007. doi: http://dx.doi. org/10.1016/j.envsoft.2005.12.005

[5] Paulo, S., Manual de Drenagem e manejo de águas pluviais: aspectos tecnológicos, diretrizes para projetos, ed. S.M.d.D.U. (SMDU), São Paulo, p. 128, 2012.

[6] Marchioni, M.L. \& Becciu, G., Permeable pavement used on sustainable drainage systems (SUDs): a synthetic review of recent literature. WIT Press Urban Water II, p. 12, 2014. doi: http://dx.doi.org/10.2495/uw140161 
[7] Pratt, C.J., Sustainable drainage: A review of published material on the performance of various SUDS components. Prepared for the Environment Agency. SUDS Science Group/99705.015, 2004.

[8] Ferguson, B.K., Porous Pavements, Taylor \& Francis, 2005.

[9] Smith, D.R., Evaluations of concrete grid pavements in the United States. Second International Conference on Concrete Block Paving, Delft, 1984.

[10] Hogland, W., Niemczynowicz, J. \& Wajlman, T., The unit superstructure during the construction period. Science of the Total Environment, 59, pp. 411-424, 1987. doi: http:// dx.doi.org/10.1016/0048-9697(87)90464-5

[11] Pratt, C.J., Permeable pavements for stormwater quality enhancement. Urban Stormwater Quality Enhancement@ sSource Control, Retrofitting, and Combined Sewer Technology, ASCE, 1990.

[12] Pratt, C.J., Mantle, J. \& Schofield, P., UK research into the performance of permeable pavement, reservoir structures in controlling stormwater discharge quantity and quality. Water Science and Technology, 32(1), pp. 63-69, 1995. doi: http://dx.doi.org/10.1016/02731223(95)00539-y

[13] Pratt, C.J., Use of permeable, reservoir pavement constructions for stormwater treatment and storage for re-use. Water Science and Technology, 39(5), pp. 145-151, 1999. doi: http://dx.doi. org/10.1016/s0273-1223(99)00096-7

[14] Legret, M., Colandini, V. \& Le Marc, C., Effects of a porous pavement with reservoir structure on the quality of runoff water and soil. Science of the Total Environment, 189-190, pp. 335-340, 1996. doi: http://dx.doi.org/10.1016/0048-9697(96)05228-x

[15] Legret, M. \& Colandini, V., Effects of a porous pavement with reservoir structure on runoff water: Water quality and fate of heavy metals. Water Science and Technology, 39(2), pp. 111-117, 1999. doi: http://dx.doi.org/10.1016/s0273-1223(99)00014-1

[16] Pagotto, C., Legret, M. \& Le Cloirec, P., Comparison of the hydraulic behaviour and the quality of highway runoff water according to the type of pavement. Water Research, 34(18), pp. 4446-4454, 2000. doi: http://dx.doi.org/10.1016/s0043-1354(00)00221-9

[17] Asaeda, T. \& Ca, V.T., Characteristics of permeable pavement during hot summer weather and impact on the thermal environment. Building and Environment, 35(4), pp. 363-375, 2000. doi: http://dx.doi.org/10.1016/s0360-1323(99)00020-7

[18] Dierkes, C., et al., Pollution retention capability and maintenance of permeable pavements, Global Solutions for Urban Drainage, Proc. of the Ninth Int. Conf. on Urban Drainage, 8-13 September 2002, Portland, OR, 2002. doi: http://dx.doi.org/10.1061/40644(2002)40

[19] Gerritts, C. \& James, W., Restoration of infiltration capacity of permeable pavers. Proceedings of 9th International Conference on Urban Drainage. ASCE. Portland, OR, 2002.

[20] Schlüter, W. \& Jefferies, C., Modelling the outflow from a porous pavement. Urban Water, 4(3), pp. 245-253, 2002. doi: http://dx.doi.org/10.1016/s1462-0758(01)00065-6

[21] Knapton, J., Cook, I.D. \& Morrell, D., A new design method for permeable pavements surface with pavers. Highway Engineer from The Institution of Highways \& Transportation, 2002.

[22] Brattebo, B.O. \& Booth, D.B., Long-term stormwater quantity and quality performance of permeable pavement systems. Water Research, 37(18), pp. 4369-4376, 2003. doi: http:// dx.doi.org/10.1016/s0043-1354(03)00410-x

[23] Bean, E.Z., et al., Study on the surface infiltration rate of permeable pavements. Proceedings of the American Society of Civil Engineers and EWRI 2004 World Water and Environmental Resources Congress, Salt Lake City, UT, USA, 2004, p. 27. 
[24] Acioli, L.A., Estudo experimental de pavimentos permeaveis para o controle de escoamento superficial na fonte, Recursos Hidricos e Saneamento Ambiental, Universidade Federeal do Rio Grande do Sul, Porto Alegre, p. 162, 2005.

[25] Jabur, A.S., Relatório final de pós-doutorado, Universidade Federal do Rio Grande do Sul, p. 42, 2013.

[26] Pellizzari, V., Avaliação da eficácia na restauração da capacidade de infiltração da camada superior de pavimentos porosos, 2013.

[27] Dreelin, E.A., Fowler, L. \& Ronald Carroll, C., A test of porous pavement effectiveness on clay soils during natural storm events. Water Research, 40(4), pp. 799-805, 2006. doi: http://dx.doi. org/10.1016/j.watres.2005.12.002

[28] Beeldens, A. \& Herrier, G., Water pervious pavement blocks: the Belgian experience, Eighth International Conference on Block Paving Materials, 2006.

[29] Van Duin, B., et al. Characterization of long-term solids removal and clogging processes in two types of permeable pavement under cold climate conditions, 11th International Conference on Urban Drainage, 2008.

[30] Knapton, J. \& McBride, C., Permeable pavements for heavily trafficked roads - a full-scale trial, 9th International Conference on Concrete Block Paving, Argentina, 2009.

[31] Collins, K.A., Hunt, W.F. \& Hathaway, J.M., Evaluation of various types of permeable pavements with respect to water quality improvement and flood control, 8th International Conference on Concrete Block Paving, San Francisco, CA, 2006. doi: http://dx.doi.org/10.13031/2013.21098

[32] Virgiliis, A.L.C.d., Procedimentos de projeto e execução de pavimentos permeáveis visando retenção e amortecimento de picos de cheias, Escola Politécnica - Engenharia de Transportes, Universidade de São Paulo: São Paulo, p. 213, 2009. doi: http://dx.doi.org/10.11606/d.3.2009. tde-08092010-122549

[33] Pinto, L.L.C.A., O desempenho de pavimentos permeáveis como medida mitigadora da impermeabilização do solo urbano, Escola Politécnica - Engenharia de Transportes, Universidade de São Paulo: São Paulo, 2011. doi: http://dx.doi.org/10.11606/t.3.2011.tde-31082011-160233

[34] Borst, M., Surface Infiltration Rates of Permeable Surfaces: Six Month Update (November 2009 through April 2010), National Risk Management Research Laboratory, Water Supply and Water Resources Division, US Environmental Protection Agency, 2010.

[35] Morgenroth, J., Buchan, G. \& Scharenbroch, B.C., Belowground effects of porous pavements - soil moisture and chemical properties. Ecological Engineering, 51, pp. 221-228, 2013. doi: http://dx.doi.org/10.1016/j.ecoleng.2012.12.041

[36] Newman, A.P., Aitken, D. \& Antizar-Ladislao, B., Stormwater quality performance of a macro-pervious pavement car park installation equipped with channel drain based oil and silt retention devices. Water Research, 47(20), pp. 7327-7336, 2013. doi: http://dx.doi. org/10.1016/j.watres.2013.05.061

[37] Smith, D.R., Permeable Interlocking Concrete Pavements, ICPI: USA, 2000.

[38] Hein, D.K., Swan, D. \& Schaus, L., Structural and hydrological design of permeable pavements, 2010 Annual Conference of the Transportation Association of Canada, Halifax, Nova Scotia, 2010.

[39] Suda, S., et al., Development and application of permeable paving concrete block, International Conference on Concrete Block Paving, 1988, 3rd, Rome, Italy, 1988.

[40] Qin, H.-P., Li, Z.-X. \& Fu, G., The effects of low impact development on urban flooding under different rainfall characteristics. Journal of Environmental Management, 129, pp. 577-585, 2013. doi: http://dx.doi.org/10.1016/j.jenvman.2013.08.026 
[41] Sansalone, J., et al., Retrofitting impervious urban infrastructure with green technology for rainfall-runoff restoration, indirect reuse and pollution load reduction. Environmental Pollution,. 183, pp. 204-212, 2013. doi: http://dx.doi.org/10.1016/j.envpol.2013.01.051

[42] Pratt, C., Newman, A. \& Bond, P., Mineral oil bio-degradation within a permeable pavement: long term observations. Water Science and Technology, 39(2), pp. 103-109, 1999. doi: http:// dx.doi.org/10.1016/s0273-1223(99)00013-x

[43] Mullaney, J., Rikalainen, P. \& Jefferies, C., Pollution profiling and particle size distribution within permeable paving units - with and without a geotextile. Management of Environmental Quality: An International Journal. 23(2), pp. 150-162, 2012. doi: http://dx.doi. org/10.1108/14777831211204903

[44] McCarthy, D.T., et al., Intra-event variability of Escherichia coli and total suspended solids in urban stormwater runoff. Water Research, 46(20), pp. 6661-6670, 2012. doi: http://dx.doi. org/10.1016/j.watres.2012.01.006

[45] Tota-Maharaj, K. \& Scholz, M., Combined permeable pavement and photocatalytic titanium dioxide oxidation system for urban run-off treatment and disinfection. Water and Environment Journal, 27(3), pp. 338-347, 2013. doi: http://dx.doi.org/10.1111/j.1747-6593.2012.00350.x

[46] Kipkie, C., Feasibility of a permeable pavement option in the storm water management model (SWMM) for long term continuous modelling. Master of Science Thesis, University of Guelph, 1998. doi: http://dx.doi.org/10.14796/jwmm.r206-18

[47] Imteaz, M.A., et al., Modelling stormwater treatment systems using MUSIC: accuracy. Resources, Conservation and Recycling, 71, pp. 15-21, 2013. doi: http://dx.doi.org/10.1016/j. resconrec.2012.11.007

[48] Borgwardt, S., Long-term in-situ infiltration performance of permeable concrete block pavement, Proceedings, 2006.

[49] Yong, C.F., McCarthy, D.T. \& Deletic, A., Predicting physical clogging of porous and permeable pavements. Journal of Hydrology, 481, pp. 48-55, 2013. doi: http://dx.doi.org/10.1016/j. jhydrol.2012.12.009

[50] de Sousa Pinto, C., Curso básico de mecânica dos solos: exercícios resolvidos, Oficina de Textos, 2001.

[51] Terzaghi, K. \& Peck, R.B., Soil Mechanics in Engineering Practice, 2nd edn, John Wiley, 1968.

[52] Marchioni, M.L. \& Silva, C.O., Método de ensaio para avaliação de pavimento permeável executado. 55th Congresso Brasileiro do Concreto CBC2013, IBRACON: Gramado, 2013.

[53] ASTM, Standard Test Method for Infiltration Rate in Place of Pervious Concrete. 2009.

[54] Smith, D.R., Earley, K. \& Lia, J.P.E., Potential application of ASTM C1701 for evaluating surface infiltration of permeable interlocking concrete pavements, 10th International Conference on Concrete Block Paving, Shanghai, 2012.

[55] Li, H., Kayhanian, M. \& Harvey, J.T., Comparative field permeability measurement of permeable pavements using ASTM C1701 and NCAT permeameter methods. Journal of Environmental Management, 118, pp. 144-152, 2013. doi: http://dx.doi.org/10.1016/ j.jenvman.2013.01.016 